\title{
IMPACT OF TEMPORARY CHANGES IN PENSION INDEXATION
}

\author{
[Dopady dočasných změn valorizace důchodů]
}

\author{
Petr Janský ${ }^{1}$ \\ ${ }^{1}$ Institut ekonomických studií, Fakulta sociálních věd, Univerzita Karlova v Praze, Opletalova 26, Praha 1, \\ 110 00, Česká republika; CERGE-EI, společné pracoviště Centra pro ekonomický výzkum a postgraduální \\ vzdělání Univerzity Karlovy a Národohospodářského ústavu AVČR, v. v. i. \\ Email:jansky.peta@gmail.com
}

\begin{abstract}
Temporary rules for indexation of old-age public pensions in the Czech Republic were introduced for the period between 2013 and 2015. The pensions are now indexed only according to the sum of a third of the wage growth and a third of price inflation. This is by two thirds of price inflation lower than in 2012. This article empirically evaluates impact of this change on expected values of pensions and compares it with seven alternative proposals. The analysis estimates that pensions will be by 5\% lower by 2015 in comparison to the earlier rules for indexation. The implemented change is the third lowest indexation out of the eight evaluated proposals. One of the main findings is that temporary changes can have an important impact beyond the short run. The temporary lower growth of pensions during the three years is naturally reflected in lower expected values of pensions and in lower public expenditures in the subsequent years.
\end{abstract}

Keywords: indexation, impact evaluation, pension, pension indexation, Czech Republic.

JEL classification: H55, H75, J18, J32

Doručeno redakci: 24.10.2013; Recenzováno: 13.5.2014; 27.5.2014; Schváleno k publikování: 23.9.2014

\section{Úvod}

Cílem uzákonění změn valorizace důchodů z roku 2011 bylo mimo jiné omezit možnosti vlády měnit valorizační schéma, tedy její diskreci v tom, jak porostou důchody. Důchodci (i veřejné rozpočty) měli mít dlouhodobější perspektivu. Již o rok později, v roce 2012, se ale vláda podobné diskrece sama dopustila, i když k tomu potřebovala změnit zákon. Vláda tedy měla v roce 2011 chvályhodnou vizi nastavit systém valorizací dlouhodobě, ale o rok později tento svůj cíl - jejími slovy kvůli veřejným rozpočtům - více méně popřela. ${ }^{1}$

V návaznosti na tyto nedávné změny $\mathrm{v}$ tomto článku představím důležité otázky týkající se valorizací důchodů. U vybraných otázek nabídnu empirické odpovědi a zaměřím se především na to, jaké jsou varianty nastavení pravidel pro valorizaci důchodů a jaké dopady mají různé návrhy valorizace na očekávanou výši důchodů. ${ }^{2}$

\footnotetext{
${ }^{1}$ I pohled do nedávné historie ukazuje, že vláda se ne vždy držela svých dříve oznámených plánů (např́ílad mimořádná valorizace $\mathrm{v}$ srpnu 2008 byla vládou zdůvodněna enormním růstem cen za období srpen 2007 až leden 2008 o $5,1 \%)$.

${ }^{2} \mathrm{~V}$ tomto článku se řadou relevantních a důležitých otázek nezabývám, protože tento článek má své vlastní zaměření a omezený rozsah. Např́klad se nezabývám způsobem výpočtu velikosti starobních důchodů nebo odlišností dopadů na různé důchodce a jejich domácnosti, což byla témata dřivějších výzkumných článků. Dopady dř́ivějších návrhů vlády na chudobu důchodců se pokusili vyč́slit Janský \& Münich (2012), kteří zároveň poznamenávají, že relativní chudoba českých důchodců nejméně ve srovnání se zahraničím není př́liš vysoká a ve srovnání se zeměmi Evropské unie patř́i mezi nejnižší. Jejich studie se zaměřila především na rozdíly mezi různými domácnostmi důchodců, kdežto tento současný článek si klade za cíl porovnat dopady různých valorizačních pravidel na očekávanou výši průměrných starobních důchodů. Výpočty velikostí starobních důchodů se zabýval Schneider (2011). Také dalším relevantním aspektům valorizací důchodů, jako např́íklad dopady na veřejné rozpočty, potenciální regresivní dopad valorizací kvưli delšímu očekávanému dožití u osob s vysokými př́ijmy, se věnuji nanejvýš okrajově.
} 
Zvolení systému valorizací je otázkou politického rozhodnutí, tedy i společenského konsenzu. Důležitou roli hraje vztah důchodů $\mathrm{k}$ veřejným financím. Je zřejmé, že štědřejší vyplácené důchody (at' už díky vyšším důchodům či následné vyšší valorizaci) znamenají vy̌šśí výdaje veřejných rozpočtů. ${ }^{3}$ Výdaje na starobní důchody představují jednu z největších výdajových položek státního rozpočtu (Janský \& Schneider, 2012). Proto i relativně malé snížení nebo nezvýšení důchodů (a výdajů na ně) znamená relativně velkou rozpočtovou úsporu. Česko tak krátkodobě i dlouhodobě stojí před nelehkým rozhodnutím, jak dilema v př́ípadě důchodů a jejich valorizace řešit.

Ve zbývající části článku hodnotím nedávnou změnu nastavení valorizací především z pohledu současných důchodců a částečně rozšiřuji hodnocení obsažené ve vládní důvodové zprávě, která hodnotí šest variant od tehdejš́ího statusu quo až po implementovanou změnu. ${ }^{4}$ Dále představuji některé aspekty valorizace důchodů včetně různých možností valorizací u nás i v zahraničí a vyhodnocuji dopady osmi různých nastavení valorizací na očekávanou výši starobních důchodů.

\section{Teoretické i praktické možnosti valorizace důchodů}

Vláda Petra Nečase se v roce 2012 rozhodla změnit nastavení valorizace důchodů a to, jak budou důchody růst v návaznosti na ekonomický vývoj. ${ }^{5}$ Od roku 2013 do roku 2015 se důchody valorizují dle součtu třetinových nárůstů jak mezd, tak cen. ${ }^{6}$ To je značný rozdíl od dřívějšího a, pro zatím podle všeho, po roce 2015 opět platného systému valorizací součtu třetinového nárůstu průměrné mzdy a celého nárůstu inflace dle indexu spotř̌ebitelských cen. Tento systém tak znamená snížení budoucích důchodů. V tomto článku kromě hodnocení dopadů schválené legislativy diskutuji další alternativy.

Vláda odůvodnila změnu valorizace především nutností uspořit výdaje rozpočtu. Slovy důvodové zprávy je cílem: „dočasně omezit v letech 2013-2015 výši zvýšení důchodů stanovenou zákonem o důchodovém pojištění a přispět tak ke stabilizaci bilance př́ijmů a výdajů státního rozpočtu. “7 Výdaje snížením růstu současných důchodů vláda nejspíše

\footnotetext{
${ }^{3} \mathrm{Na}$ výběr jsou nejméně tři možnosti, všechny s výhodami i nevýhodami: 1 . Ponechat současný, př́ípadně zavést ještě méně štědrý, systém valorizace důchodů, který zapříčiní nižší než dříve očekávané starobní důchody. Výdaje veřejných rozpočtů klesnou a bude více prostředků na jiné výdaje nebo snížení vládního zadlužení. 2. Valorizaci co nejdříve vrátit $\mathrm{k}$ dřívějšímu nebo jinému ššěřejšímu systému a související zvýšení rozpočtových výdajů financovat $\mathrm{v}$ rámci systému důchodového pojištění zvýšením odvodů na sociální pojištění. Výdaje veřejných rozpočtů vzrostou a budou financovány většími odvody ze mzdy, což demotivuje k pracovní aktivitě. 3. Valorizaci vrátit $\mathrm{k}$ dřívějšímu nebo jinému štědřejšímu systému a upřednostnit stávající starobní důchodce oproti současné úpravě a na úkor jiných, nyní existujících výdajů státního rozpočtu. Výše výdajů veřejných rozpočtů zůstane zachována, ale změní se jejich struktura. Vláda tak v této a podobných oblastech čelí těžkým rozhodnutím. Ze současného pohledu především vzhledem $\mathrm{k}$ dočasným změnám ve valorizacích volí vláda variantu č. 1 výše. Spíše než rozporovat, že 2. nebo 3. možnost by byly lepší si zde kladu za cíl podrobit toto vládní rozhodnutí komplexnější analýze.

${ }^{4} \mathrm{Na}$ důvodovou zprávu k vládnímu návrhu zákona, kterým se mění zákon č. 155/1995 Sb., o důchodovém pojištění, ve znění pozdějších předpisů, Vláda ČR (2012), v tomto článku částečně navazuji.

${ }^{5}$ Důchody, pokud není uvedeno jinak, máme na mysli starobní důchody - státní důchody z tzv. prvního pilí̌e.

6 Zásadní část změny zákona (dostupné ve sbírce zákonů (http://aplikace.mvcr.cz/sbirkazakonu/ViewFile.aspx?type=c\&id=6253) zní takto: „V $§ 67$ odst. 6 se za větu první vkládá věta „Pro zvýšení procentní výměry vyplácených důchodů v období od 1. ledna 2013 do 31. prosince 2015 se však při stanovení růstu cen podle věty první použije jen jedna třetina procentního př́rrůstku indexu spotřebitelských cen." Jak vyplývá z textu zákona, navázání na inflaci a růst mezd se týká jen procentní výměry, druhá složka důchodů základní výměra vyplácených důchodů - se zvyšuje tak, aby výše základní výměry důchodu činila 9 \% průměrné mzdy, tj. valorizuje se podle růstu průměrné mzdy. Ačkoliv se jedná o menší složku celkové výše důchodů, neměl by tento fakt chybět ve veřejné diskuzi valorizací - která se často omezuje na diskusi valorizace procentní výměry - tolik, jako je tomu nyní.

${ }^{7}$ Důvodová zpráva viz Vláda ČR (2012).
} 
opravdu sníží a ke svému cíli, stabilizaci státního rozpočtu, tedy přispěje. ${ }^{8}$ Argumentace vlády se mi ale přesto jeví jako neúplná z několika důvodů, at' už se jedná o důraz na stabilizaci státního rozpočtu (bez detailní argumentace včetně zvážení a vyloučení alternativ), nebo o rozměr časový (důvodová zpráva i politici nemají jasno v tom, co přesně chtějí po roce 2015). Vláda by také u takovéhoto rozhodnutí měla více dbát o vysvětlení sociálních aspektů (proč by se měly snižovat důchody a jestli a proč jsou nyní př́liš vysoké - zde by vláda mohla relativně silně argumentovat, že kvůli snížené valorizaci důchodů se i důchodci budou oproti očekávání ještě více podílet na ekonomickém poklesu). V odůvodnění změny valorizací by také mělo být jasnější navázání na celý důchodový systém (např́iklad zda je valorizace neměnnou součástí plnění důchodového pojištění nebo proč, když odůvodněním jsou rostoucí výdaje na důchody, se situace neřeší změnou výpočtu důchodů, ale valorizací - také viz níže diskuze substitučního vztahu mezi velikostí důchodů a jejich valorizací). Jakkoliv můžeme s vládou souhlasit či nesouhlasit, nevyužívá pro své kroky celou šíři ani hloubku argumentů, což je škoda pro ni, kvalitu veřejné diskuze a v konečném důsledku především pro občany.

Velikost starobních důchodů českého důchodového systému je obecně určena třemi hlavními faktory: nastavením vzorce pro výpočet důchodů, výší mzdy před odchodem do důchodu a valorizací, jejichž systém je předmětem tohoto článku. Souhra těchto faktorů měla relativně vyrovnaný dopad na relativní velikost důchodů v průběhu poslední dekády. Jak ukazuje tabulka 1, náhradový poměr, tedy podíl průměrného důchodu na průměrné čisté mzdě, se pohyboval několik procentních bodů pod úrovní $60 \%{ }^{9} \mathrm{Za}$ posledních pět let tento podíl zaznamenal nárůst $\mathrm{v}$ řádu procentních bodů $\mathrm{k}$ hodnotám ze začátku minulé dekády, a tak lze od roku 2000 mluvit o vývoji v podobě mělkého U.

Tabulka 1: Podíl průměrného vypláceného důchodu na průměrné mzdě, tzv. náhradový poměr, v České republice mezi roky 2000 a 2011

\begin{tabular}{|l|l|l|}
\hline Rok & V \% průměrné čisté mzdy & V \% průměrné hrubé mzdy \\
\hline 2000 & 59.9 & 46.5 \\
\hline 2001 & 58.8 & 45.7 \\
\hline 2002 & 59.1 & 45.5 \\
\hline 2003 & 58.0 & 44.5 \\
\hline 2004 & 56.3 & 42.9 \\
\hline 2005 & 57.3 & 43.5 \\
\hline 2006 & 55.7 & 43.2 \\
\hline 2007 & 55.9 & 43.1 \\
\hline 2008 & 55.9 & 42.7 \\
\hline 2009 & 57.1 & 44.3 \\
\hline 2010 & 56.3 & 43.7 \\
\hline 2011 & 57.7 & 44.6 \\
\hline 2012 I.-III.Q & 58.8 & 45.7 \\
\hline
\end{tabular}

Zdroj: VÚPSV (http://praha.vupsv.cz/Fulltext/fakta/T6.xls dle verze z 11.2. 2013)

\footnotetext{
${ }^{8}$ Z hlediska účetního je toto zřejmé - nezvýšením důchodů se nezvýší výdaje veřejných rozpočtů - ale z hlediska ekonomického, nebo, chcete-li komplexního, už to tak jasné není. Dovedu si představit, že navzdory malé relativní chudobě českých důchodců v evropském srovnání dle Janský \& Münich (2012) a relativně malým změnám jejich př́imů kvůli změně valorizací existuje v návaznosti na zhoršení jejich situace riziko nárůstu státních výdajů např́íklad na dlouhodobou a sociální péči nebo zdravotní služby, které by kompenzovalo plánované úspory. Tato a podobné otázky ale nejsou zaměřením tohoto článku, a proto se podrobně nevěnuji jejich zodpovídání.

${ }_{9}$ Naprostá většina důchodů není zdaněna, a pro mnohé účely je proto vhodné porovnávat výši důchodů s čistou mzdou, i když častěji se využívá srovnání s hrubou mzdou, a proto jej preferuji i v analytické části tohoto článku.
} 
Pro valorizace důchodů mohou být různé důvody a její motivací může být at' už udržení absolutní životní úrovně důchodců vůči změnám cen, nebo snaha o udržení relativní životní úrovně důchodců vůči zbytku společnosti, vymezené např́íklad vůči změnám mezd. ${ }^{10}$ Důležitou motivací pro systematickou valorizaci může být také snaha co nejvíce důchody ochránit před vlivem politických změn. Ucelený pohled na problematiku valorizací přináśí a řadu důvodů pro valorizaci především z pohledu nesení rizika diskutuje Whitehouse (2009). Valorizaci lze považovat také za součást celého důchodového balíčku s tím, že může existovat substituční vztah mezi štědrostí náhradového poměru přiznaného důchodu a jeho následnou valorizací; využití tohoto vztahu bylo důležitým aspektem italské reformy důchodového systému z poloviny 90. let minulého století (Gronchi \& Aprile, 1998). Nižší očekávaná valorizace tedy, alespoň teoreticky, znamená vyšší důchod na začátku jeho čerpání. Tyto a další důvody se odráží v nastavení valorizací v různé míre, v různých časových obdobích, u nás nebo v zahraničí. ${ }^{11}$

Valorizovat důchody lze podle řady kritérií a jejich kombinací. Důvodová zpráva k vládnímu návrhu zákona nabídla 6 možností valorizací uvedených v tabulce 2. Valorizace důchodů o $100 \%$ růstu cen preferoval ve svém volebním programu prezident Miloš Zeman. ${ }^{12}$

Tabulka 2: Možné varianty změn valorizace důchodů dle vládní důvodové zprávy

\begin{tabular}{|l|l|}
\hline Varianta & Popis \\
\hline 1 & $\begin{array}{l}\text { Zvyšování o } 100 \% \text { růstu cen a } 1 / 3 \text { růstu reálných mezd. } \\
\text { Tato varianta představuje stav před rokem } 2013 \text { (a po roce 2015) a je tedy } \\
\text { výchozím stavem pro analýzu dopadů následných změn. }\end{array}$ \\
\hline 2 & $\begin{array}{l}\text { Zvyšování o } 100 \% \text { růstu cen. } \\
\text { Při této variantě se nebude zohledňovat mzdový vývoj, ale dojde pouze ke } \\
\text { kompenzaci růstu cen. Varianta preferovaná budoucím prezidentem Milošem } \\
\text { Zemanem. }\end{array}$ \\
\hline 3 & $\begin{array}{l}\text { Zvyšování o } 50 \% \text { růstu cen a } 1 / 3 \text { růstu reálných mezd. } \\
\text { Oproti variantě } 1 \text { bude růst cen kompenzován pouze z jedné poloviny. }\end{array}$ \\
\hline 4 & $\begin{array}{l}\text { Zvyšování o } 1 / 3 \text { růstu cen a } 1 / 3 \text { růstu reálných mezd. } \\
\text { Při této variantě by byl obecný ekonomický vývoj kompenzován pouze z } 1 / 3, \\
\text { což je varianta vybraná a prosazená vládou pro roky } 2013-2015 .\end{array}$ \\
\hline 5 & $\begin{array}{l}\text { Zachování výše základní výměry důchodu na úrovni } 9 \% \text { prúmérné mzdy a } \\
\text { nezvyšování procentní výměry důchodu. }\end{array}$ \\
\hline 6 & Nezvyšování základní ani procentní výměry důchodu. \\
\hline Zdroj: Vláda ČR (2012)
\end{tabular}

\footnotetext{
${ }^{10}$ Podobně tyto cíle chápe i např́klad (Pilný, 2001), který na straně 156 píše: „Cílem valorizace podle cen je zachovat reálnou hodnotu důchodu a tím zabránit poklesu jeho kupní síly... Cílem valorizace podle mezd je zabezpečit proporcionální vývoj důchodů a mezd.“

${ }^{11}$ Akademická literatura v Česku i v zahraničí zkoumá valorizace jako součást důchodových systémů, ale málokdy jsou př́mo ve středu výzkumného zájmu a z podobného úhlu jako v tomto článku. Spíše výjimkou je nedávný článek Fernándeze (2012), který zkoumá zavádění valorizací v zemích OECD mezi lety 1945 a 2000. Ze zahraniční literatury dále zmíním několik studií, které se v poslední době věnují rigorózně důchodovým systémům včetně zahrnutí valorizací - například Diamond (2004), Thøgersen (2006) nebo Auerbach \& Lee (2011). Z české literatury např́klad Pilný (2001) diskutuje různé valorizační systémy a jejich dopady. Dušek (2007) se dívá na diskreci vlády ohledně valorizace důchodů jako na zdroj agregátní i individuální nejistoty, který činní český důchodový systém náchylný k politickému riziku.

${ }^{12}$ Miloš Zeman se ve svém volebním programu vyjadřuje se $\mathrm{i} \mathrm{k}$ valorizaci důchodů a $\mathrm{k}$ tomu, jak budou důchody růst v návaznosti na ekonomický vývoj: „Starobní důchody by měly být valorizovány v souladu s inflací, aby byla zachována jejich kupní síla, a to stejnou částkou pro všechny starobní důchodce.“ Citováno dle jeho volebního programu na internetových stránkách (http://www.zemannahrad.cz/fakta/program-milosezemana.htm, navštíveny 6.2.2013) a také v návaznosti na zprávu Aktuálně.cz (http://aktualne.centrum.cz/domaci/politika/clanek.phtml?id=770292).
} 
Inspirace, jak ještě lze nejen teoreticky, ale i prakticky valorizovat důchody, je k dispozici v ostatních zemích Evropské unie. Tabulka A1 v príloze ukazuje informace ze studie Evropské komise z roku 2009 o pravidlech valorizace jednotlivých typů důchodů v členských zemích Evropské unie a Norska. Další inspiraci nabízí např́íklad Whitehouse (2009).

Pro analýzu dopadů různých valorizačních schémat na velikost důchodů v další části článku vybírám kromě prvních šesti vládou zvažovaných variant (1 až 6) i dvě (7 až 8), které jsou vedeny cílem udržet reálnou životní úroveň důchodců a inspirované především českými opozičními návrhy, jak vysvětluje tabulka 3.

Tabulka 3: Alternativní české návrhy valorizace důchodů

\begin{tabular}{|l|l|}
\hline Varianta & Popis \\
\hline 7 & $\begin{array}{l}100 \% \text { růst indexu životních nákladů důchodců }+1 / 3 \text { reálných mezd (při růstu } \\
\text { cen 5\% mimořádné zvýšení procentní výměry) } \\
\text { (inspirován návrhy ČSSD, KSČM a ČMKOS na základě jejich dlouhodobých } \\
\text { programů a dalších dokumentů) }\end{array}$ \\
\hline 8 & $\begin{array}{l}\text { Valorizace podle } 100 \% \text { indexu životních nákladů důchodců }+1 / 2 \text { reálných } \\
\text { mezd } \\
\text { (inspirován dřívějším návrhem poslanců KSČM) }\end{array}$ \\
\hline
\end{tabular}

Zdroj: ČSSD: Důchodová reforma ČSSD (http://www.cssd.cz/data/files/duchody-0004.pdf); KSČM (volební program 2006-2010); ČMKOS - Návrh důchodové reformy ČMKOS; dřívější návrh poslanců KSČM (http://www.kscm.cz/uvodni-stranka/27989/navrh-novely-zakona-o-duchodovem-pojisteni-z-dilny-

komunistickych-poslancu?\&previev=archiv)

\section{Empirická analýza dopadů valorizace důchodů}

V této části se soustředím na představení výsledků analýzy dopadů různých valorizací důchodů, nejprve však popisuji využitou metodologii včetně předpokladů. Pro odhady dopadů různých valorizací na průměrný důchod ${ }^{13}$ jsou zásadní předpoklady o budoucím vývoji veličin, na kterých závisí výše valorizace, především o vývoji průměrné mzdy a indexu spotřebitelských cen. Pro roky 2012 až 2015 využívám existující čísla a odhady ministerstev financí a práce a sociálních věcí, České národní banky a také informace z Vláda ČR (2012). Pro období od roku 2015 se spoléhám na následující předpoklady o vývoji těchto veličin: inflace $2 \%$ (což je dlouhodobý inflační cíl České národní banky), růst hrubé mzdy $4 \%$, růst reálné mzdy $2 \%$, růst životních nákladů domácností důchodců $2,7 \%{ }^{14}$. I vzhledem $\mathrm{k}$ tomu, že mi jde spíše o vzájemné srovnání různých variant než o přesné korunové vyjádření, věřím, že tyto předpoklady jsou vhodné. ${ }^{15}$ Dále pro jednoduchost prezentuji výsledky $\mathrm{v}$ dnešních korunách. ${ }^{16}$

\footnotetext{
${ }^{13}$ Výpočty nejsou s výjimkou prvních třech let platné pro průměrný důchod v daných letech, ale pro velikost průměrného roku z let 2012 až 2015 a dále z roku 2015. Nezohledňuji tedy např́íklad, kolik se v daném roce vyplácí nových důchodů.

${ }_{14}$ Tento růst životních nákladů domácností důchodců byl odhadnut jako inflace vynásobená historickým koeficientem rozdílu inflace a nákladů důchodců na základě informací Českého statistického úřadu

${ }^{15}$ Použití jiných makroekonomických předpokladů by mohlo výrazně změnit absolutní výsledky, ne však př́lišs relativní výsledky různých variant valorizací (s výjimkou velmi rozdílných vývojů cen a mezd nebo například deflace). Zaměřením článku jsou různá valorizační pravidla, ne makroekonomický vývoj, a proto využívám pouze výše uvedené, jednoduché předpoklady.

${ }^{16}$ Dalším aspektem, který nezohledňuji, je účinnost valorizací v čase, s kterou jsou spojeny nejméně dvě důležité otázky. Za prvé, teoreticky je možné, že by po snížených valorizacích důchodů během období 2013 až 2015 vláda kompenzovala výši důchodů tak, aby se náhradový poměr skokově vrátil na úroveň, na které by byl bez dočasného snížení valorizace. Tuto možnost jsem uvažoval v pracovních výpočtech, ale ve výsledcích zde uvažuji absenci jakékoliv kompenzace. Za druhé, po dočasné změně by bylo možné důchodce jednorázově kompenzovat za nižší než dříve očekávané důchody kvůli nižším valorizacím. V tom případě by opatření téměř neřešilo problém implicitního deficitu českého důchodového systému a šlo by pouze o přenesení problému
} 
Obrázek 1 ukazuje poměr valorizovaného dnešního průměrného důchodu (který se obecně nedaní) $\mathrm{k}$ budoucí průměrné hrubé mzdě podle současného pravidla valorizace a ve srovnání s alternativami od roku 2013 po rok 2015, tedy po dobu trvání této zákonem potvrzené výjimky. Schválená varianta 4 nabízí třetí nejnižší míru valorizace $\mathrm{z}$ hodnocených možností a sníží poměr důchodu $\mathrm{k}$ hrubé průměrné mzdě ze 41,6 \% v roce 2012 na 38,3\% v roce 2015. Obrázek 1 dále ukazuje, že jen varianty 7 a 8 - nezvažované vládou - představují štědřejší valorizaci důchodů než původní nastavení valorizace (varianta 1), což není překvapivé, protože cílem vlády bylo ušetřit a tedy zmenšit očekávanou hodnotu důchodů.

Obrázek 1: Poměr valorizovaného dnešního průměrného důchodu k průměrné hrubé mzdě podle současného pravidla valorizace a ve srovnání s alternativami do roku 2015

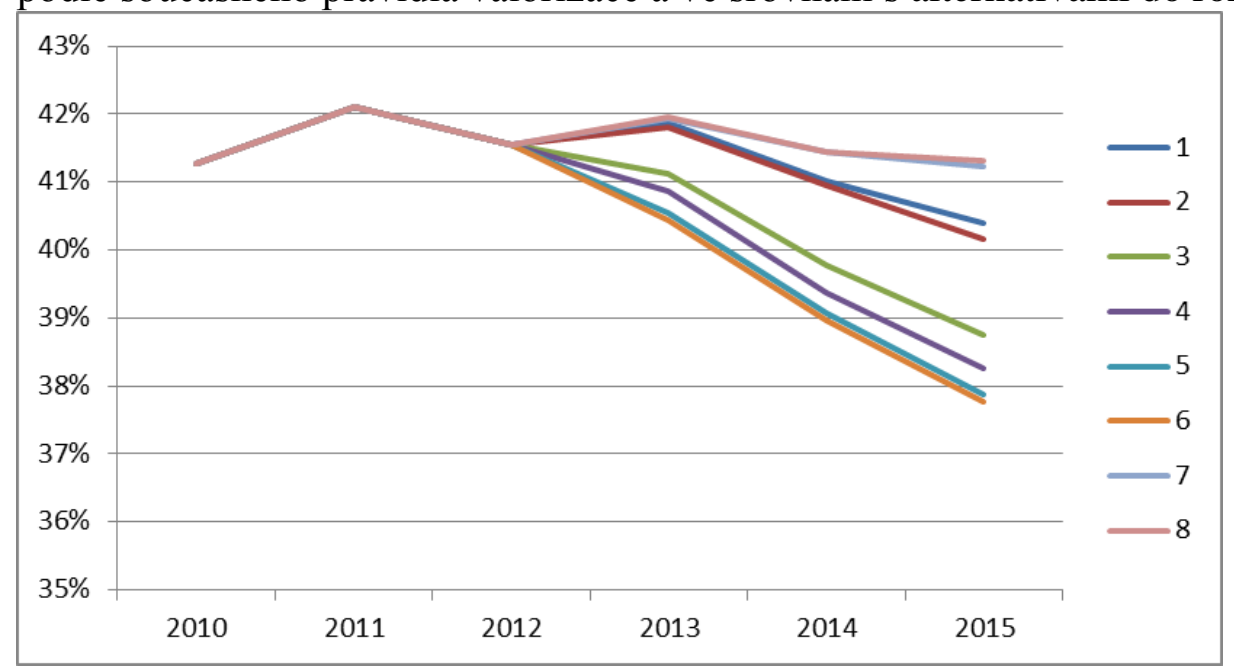

Zdroj: Data a metody v tomto článku popsané.

Obrázek 2 zachycuje totéž co obrázek 1, ale v procentuálním vyjádření valorizačních alternativ vůči alternativě 1 , tedy situaci v roce 2012. Z výsledků v obrázku 2 vyplývá, že na konci období pro dočasnou valorizaci lze očekávat důchody o $5 \%$ nižší než podle dřívější valorizace, což představuje třetí nejnižší valorizaci z osmi hodnocených návrhů.

Obrázek 2: Procentuální vyjádření alternativních nastavení valorizace vůči stavu v roce 2012

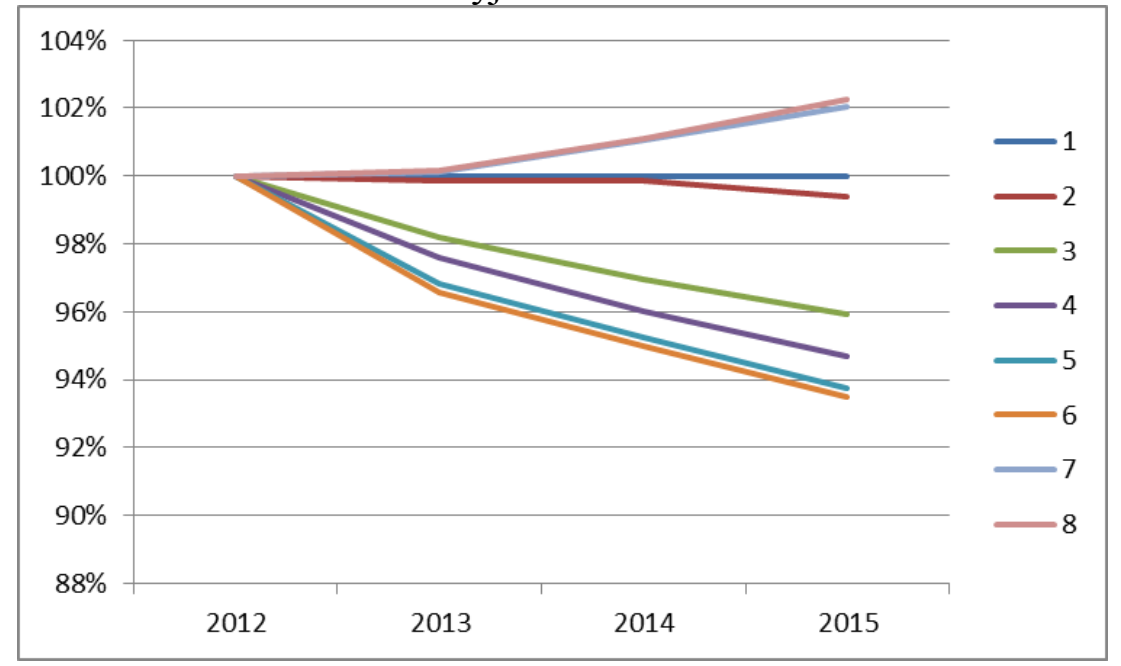

Zdroj: Data a metody v tomto článku popsané.

do budoucnosti na bedra prŕšstích vlád. Proto tuto kompenzaci nepovažuji za př́liš pravděpodobnou, vládní dokumenty ji nezmiňují, a proto ji v tomto článku nijak nevyhodnocuji. 
Jak ukazuje obrázek 3, i dočasná změna s sebou nese dlouhodobé důsledky. Obrázek 3 ukazuje poměr valorizovaného dnešního průměrného důchodu $\mathrm{k}$ budoucí průměrné hrubé mzdě podle současného pravidla valorizace a ve srovnání s alternativami od roku 2013 po rok 2030 s tím, že mezi roky 2013 a 2015 počítá pro jednotlivé varianty valorizaci dle těchto pravidel a mezi roky 2016 a 2030 pak dle varianty $1 .{ }^{17}$ Modelovaný vývoj mezi roky 2013 a 2015 nabízí rozdílné výsledky po těchto třech letech. Tyto rozdíly ale přetrvávají, jelikož rozdílný růst důchodů $\mathrm{v}$ různých variantách není při návratu $\mathrm{k}$ dřívějšímu systému od roku 2016 nijak kompenzován. Dočasné změny valorizací tedy mají znatelný vliv i poté, co již nejsou platné.

Obrázek 3: Poměr valorizovaného dnešního průměrného důchodu k průměrné hrubé mzdě pro různé alternativní valorizace pro roky 2013 až 2015 a dle současného pravidla valorizace pro roky 2016 až 2030

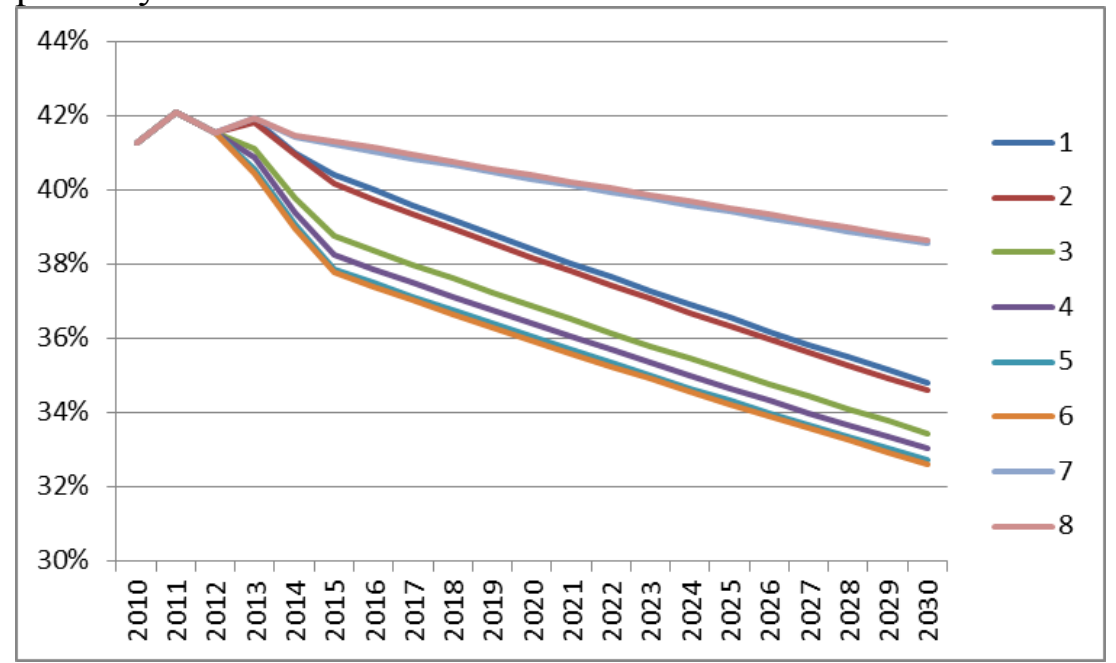

Zdroj: Data a metody v tomto článku popsané.

Jak ukazují obrázky 1 až 3, oproti současnému stavu všechny ostatní vládou zvažované alternativy (2 až 6) snižují očekávanou velikost důchodů během tohoto dle vlády výjimečného tř́iletého období (což - vzhledem k jejich specifikaci a cíli snížení vládních výdajů - není překvapivé). Tabulka A2 v př́loze ukazuje, o kolik by kumulovaně při daných variantách důchodci přišli, popř́ípadě získali navíc, za daný časový úsek oproti původnímu systému valorizací. Tyto údaje nejsou příliš užitečné z pohledu analýzy a potvrzují trendy představené výše, ale prezentuji je zde pro úplnost.

V tabulce 4 uvádím porovnání původního a budoucího systému valorizace podle dopadů na státní výdaje a velikost průměrného starobního důchodu. Výsledky ukazují, že změnou z původního (zvyšování o $100 \%$ růstu cen a $1 / 3$ růstu reálných mezd) na nový systém (zvyšování o $1 / 3$ růstu cen a $1 / 3$ růstu reálných mezd), přijde důchodce po třech letech jeho platnosti měsíčně průměrně o 626 Kč a státnímu rozpočtu se za rok 2015 sníží výdaje o 22 miliard korun. Tyto snížené výdaje veřejných rozpočtů budou pokračovat i po roce 2015, ale přirozeně se spolu se snižujícím se počtem důchodů, které ovlivnila dočasná valorizace mezi lety 2013 a 2015, bude těchto 22 miliard postupně snižovat až na nulu.

\footnotetext{
${ }^{17}$ Toto časové období jsme vybrali jako nejvíce ilustrativní na základě následující jednoduché úvahy. Muži narození v roce 1950 mohou či mohli jít do starobního důchodu v roce 2012 a 2013 (na základě informací MPSV a s výjimkou předčasného důchodu) a mají v těchto letech naději na dožití (jak vyplývá ze Statistické ročenky 2012, strana 143 http://www.czso.cz/csu/2012edicniplan.nsf/t/A6004C2345/\$File/000112.pdf) zhruba 17 až 18 let. Sečtením těchto čísel jsme dospěli k horizontu roku 2030, který není nijak zavazující; jen pro tento interval prezentuji výsledky.
} 
Tabulka 4: Výdaje na důchody a průměrná výše starobního důchodu

\begin{tabular}{|c|c|c|c|c|}
\hline Rok & $\begin{array}{l}\text { Výdaje na } \\
\text { důchody } \\
\text { dle původní } \\
\text { valorizace v } \\
\text { miliardách Kě }\end{array}$ & $\begin{array}{l}\text { Výdaje na } \\
\text { důchody } \\
\text { po změně } \\
\text { valorizace v } \\
\text { miliardách Kě }\end{array}$ & $\begin{array}{l}\text { Průměrný } \\
\text { starobní } \\
\text { důchod } \\
\text { původní } \\
\text { valorizace } \quad \text { v } \\
\text { Ǩ̃ }\end{array}$ & $\begin{array}{l}\text { Průměrný } \\
\text { starobní } \\
\text { důchod } \\
\text { změně } \\
\text { valorizace } \\
\text { Ǩ̃ }\end{array}$ \\
\hline 2007 & 282,9 mld. & & 8747 & \\
\hline 2008 & 305,5 mld. & & 9638 & \\
\hline 2009 & 331,7 mld. & & 10045 & \\
\hline 2010 & 340,2 mld. & & 10123 & \\
\hline 2011 & 359,1 mld. & & 10552 & \\
\hline 2012 & 373,8 mld. & & 10770 & \\
\hline 2013 & 394 mld. & 384,4 mld. & 11198 & 10926 \\
\hline 2014 & 407,6 mld. & 391,4 mld. & 11476 & 11016 \\
\hline 2015 & 423,9 mld. & 401,7 mld. & 11779 & 11153 \\
\hline
\end{tabular}

Zdroj: ČSSZ (2012) a Vláda ČR (2012)

Poznámky: Průmérným starobním důchodem je zde rozuměn sólo důchod za daný rok $k 31.12$.

\section{Závěr}

Od roku 2013 do roku 2015 platí dočasné nastavení valorizací důchodů. Ukázal jsem, že tyto a další málo diskutované časové aspekty pravidel valorizace hrají důležitou roli pro očekávanou výši starobních důchodů, a to i po návratu valorizací $\mathrm{k}$ původnímu pravidlu po roce 2015. Odhadl jsem, o kolik by se očekávaná výše důchodů mohla změnit v návaznosti na změnu valorizačních pravidel a spolu s využitím zahraničních zkušeností jsem rozšířil vládní hodnocení. Výsledky ukazují, že schválená varianta valorizace nabízí třetí nejnižší míru valorizace z hodnocených možností, což není překvapující vzhledem $\mathrm{k}$ cíli snížit zatížení veřejných rozpočtů. Vláda bohužel př́liš nevysvětlila - s výjimkou tohoto rozpočtového argumentu - proč ke změně valorizací mělo dojít.

Vláda premiéra Nečase se nejprve pokusila stabilizovat valorizaci důchodů, ale následně přišla s výjimkou na roky 2013-2015 I když na to vláda měla právo, je na místě otázka, zda lze změny valorizací lze očekávat i v budoucnu. Poslední vývoj na přelomu let 2013 a 2014 ukazuje, že nová vláda premiéra Sobotky nebude měnit jen dočasné změny valorizací, ale celé jejich nastavení - jak přesně, ukáže až čas.

Také zůstává otázkou i pro další výzkum, zda se nezamyslet nad náklady a přínosy svázaných pravidel valorizací. K jasnému zodpovězení této otázky (a podobných) by byl ale mimo jiné třeba konzistentní vztah vlády (ideálně ve spolupráci s opozicí) k roli prvního, státního pilíře důchodového systému. Ten je - ač se to i na základě debaty o valorizacích nemusí zdát alespoň nominálně dávkově definovaným pojištěním. Krokem správným směrem by mohla vykročit expertní komise zrrízená vládou v první polovině roku 2014 k zlepšení důchodového systému, nyní je ale předčasné hodnotit její práci, natož pak kolik si z ní vláda vezme za své.

Kdybych měl poradit správné nastavení valorizací, potřeboval bych nejprve vyjasnění jejich politických cílů. K čemu vlastně mají valorizace důchodů sloužit? Až jasné zodpovězení této otázky od tvůrců důchodové politiky, našich volených zástupců, by mi umožnilo navrhnout konkrétní nastavení valorizací. Navíc by se zároveň dal pravděpodobně zjednodušit současný 
relativně složitý systém. Dnes se různým způsobem valorizují dvě součásti důchodu, ačkoliv důchodce i veřejné rozpočty zajímá především výsledná výše důchodů.

\section{Poděkování}

Autor děkuje za výbornou výzkumnou asistenci Václavovi Korbelovi a za podnětné komentáře k dřívějším verzím tohoto článku děkuje Liboru Duškovi, Václavovi Korbelovi, Danielu Münichovi, Filipu Pertoldovi, Janu Strakovi a Zuzaně Šmídové.

\section{Literatura}

[1] AUERBACH, A. J. and R. LEE, 2011. Welfare and generational equity in sustainable unfunded pension systems. Journal of public economics, 95(1), 16-27. ISSN 0047-2727.

[2] DIAMOND, P., 2004. Social Security. American Economic Review, 94(1), 1-24. ISSN 0002-8282.

[3] DUŠEK, L., 2007. Political risk of social security: The case of the indexation of benefits in the Czech Republic. CERGE-EI working paper 318 [online]. [vid. 29. záŕí 2012]. Dostupné z: http://papers.ssrn.com/sol3/papers.cfm?abstract_id=1115289

[4] Důvodová zpráva k vládnímu návrhu zákona, kterým se mění zákon č. 155/1995 Sb., o důchodovém pojištění, ve znění pozdějších předpisů. Vláda $\check{C} R$ [online]. Dostupné z: http://www.psp.cz/sqw/text/tiskt.sqw?O=6\&CT=659\&CT1 $=0$

[5] EUROPEAN COMMISSION, 2009. Dealing with the impact of an ageing population in the EU (2009 Ageing Report). COM(2009) 180 [online]. Dostupné z: http://eurlex.europa.eu/legal-content/EN/TXT/?uri=CELEX:52009DC0180

[6] FERNÁNDEZ, J. J., 2012. Explaining the introduction of automatic pension indexation provisions in 17 OECD countries, 1945-2000. Journal of European Social Policy, 22(3), 241-258. ISSN 1461-7269.

[7] GRONCHI, S. and R. APRILE, 1998. The 1995 Pension Reform: Equity, Sustainability and Indexation. Labour, 12(1), 67-100. ISSN 1467-9914.

[8] JANSKÝ, P. a D. MÜNICH, 2012. Co když vlády nebudou valorizovat starobní důchody? První odhady dopadů na relativní chudobu důchodců v ČR. CERGE-EI [online]. Dostupné $\quad \mathrm{z}$ : http://iweb.cerge-ei.cz/news/in_the_media/data/kratka_ studie_2012_2.pdf

[9] JANSKÝ, P. a O. SCHNEIDER, 2012. (Ne)udržitelnost (dluhu) veřejných financí. CERGE-EI [online]. [vid. 29. zárí 2012]. Dostupné z: http://idea.cergeei.cz/documents/kratka_studie_2012_1.pdf

[10] PILNÝ, J., 2001. Návrh důchodové reformy v ČR. Scientific papers of the University of Pardubice. Series D Faculty of Economics and Administration. 6 (2001) [online]. [vid. 29. zář́ 2012]. Dostupné z: http://dspace.upce.cz/handle/10195/32255

[11] SCHNEIDER, O., 2011. Penzijní dluh - Břímě mladých. CERGE-EI [online]. Dostupné z: http://idea.cerge-ei.cz/documents/Studie_2011_02_Penze.pdf

[12] Statistická ročenka z oblasti důchodového pojištění za rok 2011. Česká správa sociálního zabezpečeni [online]. Dostupné z: http://www.cssz.cz/cz/o-cssz/informace/informacnimaterialy/statisticke-rocenky.htm

[13] THØGERSEN, Ø., 2006. Intergenerational Risk Sharing by Means of Pay-as-you-go Programs - an Investigation of Alternative Mechanisms. CESifo Working Paper Series, 
CESifo Group Munich [online]. [vid. 29. záŕí 2012]. Dostupné z: http://ideas.repec.org/p/ces/ceswps/_1759.html

[14] WHITEHOUSE, E. R., 2009. Pensions, purchasing-power risk, inflation and indexation. OECD Social, Employment and Migration Working Papers, No. 77, OECD Publishing [online]. [vid. 11. února 2013]. Dostupné z: http://develop.fafo.no/ files/news/9282/5Pensions, \%20Purchasing-Power\%20Risk,\%20Inflation\%20and\% 20Indexation.pdf 


\section{Př́lohy}

Tabulka A1: Valorizace důchodů v evropských zemích

\begin{tabular}{|c|c|c|}
\hline Země & Minimální důchod & Starobní důchod \\
\hline Belgie & $\mathrm{P}+\check{Z} \mathrm{U}^{\prime}$ & $\mathrm{P}+\check{Z} \mathbf{U}^{\prime}$ \\
\hline Bulharsko & $50 \% \mathrm{P}+50 \% \mathrm{NI}$ & $50 \% \mathrm{P}+50 \% \mathrm{NI}$ \\
\hline $\begin{array}{l}\text { Česká } \\
\text { republika }\end{array}$ & NP & $P+1 / 3 R I$ \\
\hline Dánsko & NI & NI \\
\hline Estonsko & $80 \% \mathrm{P}+20 \% \mathrm{NI}$ & $80 \% \mathrm{P}+20 \% \mathrm{NI}$ \\
\hline Finsko & $\mathrm{P}$ & $80 \% \mathrm{P}+20 \% \mathrm{NI}+$ udrž \\
\hline Francie & $\mathrm{P}$ & $\mathrm{P}$ \\
\hline Irsko & NP & NP \\
\hline Itálie & P nebo nominálně, Fixní & $\mathrm{P}+\mathrm{vel}$ \\
\hline Kypr & NI & Zákl.: NI;Dopl.: P \\
\hline Litva & NP & NP \\
\hline Lotyšsko & $\mathrm{P}+50 \% \mathrm{RI}$ & $\mathrm{P}+50 \% \mathrm{RI}$ \\
\hline Lucembursko & $\begin{array}{lrr}\mathrm{P} & \mathrm{když} & \mathrm{P}>2,5 \% \\
\text { A RI re-exam(2) } & \end{array}$ & 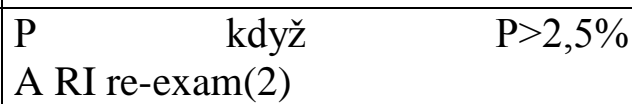 \\
\hline Mad'arsko & - & $50 \% \mathrm{P}+50 \% \mathrm{NI}$ \\
\hline Malta & $2 / 3 \check{Z ̌ N}$ & $\begin{array}{l}\text { ŽN + NI (nar. před 1962); } 70 \% \text { NI } \\
+\quad 30 \% \\
\text { (nar. po 1962) }\end{array}$ \\
\hline Německo & $\begin{array}{lll}\text { stejné } & \text { jako } & \text { penze } \\
\text { A re-exam(5) } & & \end{array}$ & $\mathrm{NI}+$ udrž \\
\hline Nizozemsko & NI & $\mathrm{NI}$ \\
\hline Norsko & NI & $\mathrm{NI}$ \\
\hline Polsko & $\mathrm{P}+20 \% \mathrm{RI}$ & $\mathrm{P}+20 \% \mathrm{RI}$ \\
\hline Portugalsko & $\mathrm{P}+$ HDP částečně (HDP) & P + HDP částečně (vel a HDP) \\
\hline Rakousko & $\mathrm{P}$ & $\mathrm{P}$ \\
\hline Rumunsko & RI & RI \\
\hline Řecko & $\mathrm{NP}$ & NP \\
\hline Slovensko & NP & $50 \% \mathrm{P}+50 \% \mathrm{NI}$ \\
\hline Slovinsko & stejné jako penze & NI a udrž \\
\hline Španělsko & $\mathrm{P}$ & $\mathrm{P}$ \\
\hline Švédsko & $\mathrm{P}$ & NI a udrž \\
\hline Velká Británie & NI & NI \\
\hline
\end{tabular}

Zdroj: (European Commission 2009)

Poznámky: Údaje se vztahují k roku 2009 a dř́ve, viz (European Commission 2009). Vysvětlení využitých zkratek: NP (neexistuji pravidla), RI (ri̊st reálné mzdy), NI (rưst nominální mzdy), HDP (rưst HDP), P (CPI inflace), ŽÚ (valorizace podle životní úrovnè), ŽN (valorizace podle životních nákladü), Vel (podle velikosti penze), Udrž. (Dodatečné úpravy podle jiných mechanismů jako udržitelnost, vyrovnávací mechanismus, očekávané doby dožití, výšse důchodu apod.), re-exam(X) (přezkoumání výše penzí každých X let), Min (minimálně). U této tabulky je nutné také poznamenat, že je převzata od Evropské komise a neni aktualizovaná na dnešní stav a u některých zemí došlo ke změnám, které často snižuji očekávané výše důchodů. 
Tabulka A2: Hrubý odhad kumulovaných korunových ztrát nebo zisků pro důchodce (a opačně pro státní důchodový účet či rozpočet) za uplynulé období

\begin{tabular}{|l|l|l|l|}
\hline Varianta & 2013 & $2013-2014$ & $2013-2015$ \\
\hline 1 & 0 & 0 & 0 \\
\hline 2 & -204 & -408 & -1272 \\
\hline 3 & -2448 & -6624 & -12372 \\
\hline 4 & -3264 & -8784 & -16296 \\
\hline 5 & -4296 & -10848 & -19716 \\
\hline 6 & -4656 & -11568 & -20796 \\
\hline 7 & 168 & 1608 & 4475 \\
\hline 8 & 219 & 1712 & 4910 \\
\hline
\end{tabular}

Poznámky: Výpočet je suma rozdílů dané varianty se stávajicí platnou variantou. To znamená, že za dané období $v$ každém měsici udělám korunový rozdil a následně všse sečtu. Jedná se o velmi hrubý odhad založený na předpokladech popsaných $v$ textu. 